\title{
Reproduction and management of the mangrove crab Ucides cordatus (Crustacea, Brachyura, Ucididae) at Iguape, São Paulo, Brazil
}

\author{
BRUNO S. SANT'ANNA ${ }^{1,2}$, ROBERTO P. BORGES ${ }^{3}$, \\ GUSTAVO Y. HATTORI ${ }^{2}$ and MARCELO A. A. PINHEIRO ${ }^{4}$ \\ ${ }^{1}$ Programa de Pós-Graduação em Aquicultura e Pesca, Instituto de Pesca do Estado de São Paulo, \\ Rua Francisco Matarazzo, 455, 05001-970 São Paulo, SP, Brasil \\ ${ }^{2}$ Universidade Federal do Amazonas/UFAM, Instituto de Ciências Exatas e Tecnologia/ICET, \\ Rua N. Sra. do Rosário, 3863, 69103-128 Itacoatiara, AM, Brasil \\ ${ }^{3}$ Universidade Santa Cecília/UNISANTA, Rua Oswaldo Cruz, 266, 11045-100 Santos, SP, Brasil \\ ${ }^{4}$ Universidade Estadual Paulista/UNESP, Campus Experimental do Litoral Paulista/ CLP, \\ Praça Infante D. Henrique, s/n, Parque Bitarú, 11330-900 São Vicente, SP, Brasil \\ Manuscript received on February 24, 2014 accepted for publication on May 2, 2014
}

\begin{abstract}
The mangrove crab Ucides cordatus is one of the most exploited crustaceans in Brazil. The present study investigated the breeding season of this species and the period of the "andada" phenomenon, when the crabs are active outside their burrows and perform agonistic behaviors. Furthermore related them to environmental factors, in a mangrove on the coast of Brazil, with inferences about management of this crab. The crabs reproduced from October through February. The "andada" occurred from November through February, with typical characteristics in the first two months, during the full and new moon periods, and was influenced positively by the air and soil temperature, luminosity, and tidal amplitude, and negatively by salinity. Based on the results of the present study, the period when the "andada" occurs in other parts of Brazil could be defined, which will aid in managing this fishery. For Iguape, state of São Paulo, Brazil, we suggest a legal off-season for both sexes in December or during the full and new moon, including January.
\end{abstract}

Key words: Brachyura, crab, mangrove, management, reproduction.

\section{INTRODUCTION}

Ucides cordatus (Linnaeus, 1763) is a very important economic resource in mangrove areas of Brazil. It is taken along the entire coast, particularly in the northern and northeastern parts of the country (IBAMA 1994, Monteiro and Coelho-Filho 2004). Studies on the reproduction of $U$. cordatus began in the middle of the last century (Oliveira 1946),

Correspondence to: Bruno Sampaio Sant'Anna

E-mail: brunusant@hotmail.com and have increased in recent years (Góes et al. 2000, Hattori and Pinheiro 2003, Pinheiro and Hattori 2003, Pinheiro et al. 2003), particularly because of damages to natural stocks as a result of intense exploitation. In southern and southeastern Brazil this crab is also intensively exploited, leading to recent preoccupation with regards to its reproduction (Góes et al. 2000, Dalabona and Silva 2005, Sant'Anna et al. 2007) and the implementation of off-season regulations (Rodrigues et al. 2000). 
Many decapod crustaceans increase their locomotor activity during the breeding season, and some make long migrations to mate and hatch their eggs. Well-known examples include the autumn migration of the lobster Palinurus argus (Latreille, 1804) reported by Brusca and Brusca (2003), and the geocarcinid Gecarcoidea natalis (Pocock, 1888), which during the rainy season migrates from the tropical forest to the sea, where they mate and hatch their eggs (Debelius 1999). Migratory behavior may be synchronized with abiotic factors such as precipitation, relative humidity, and the lunar cycle (Adamczewska and Morris 1998, Debelius 1999). Korringa (1947) and Mileikovsky (1970) also noted the association of reproduction of marine organisms with the lunar phases, such as $G$. natalis which arrives at the sea in synchrony with the highest tidal amplitudes (Debelius 1999).

In Ocypodidae mangrove crabs, reproductive events are associated with environmental rhythms (Bezerra and Matthews-Cascon 2007, Litulo 2006). Oliveira (1946) reported a correlation between the "andada" of $U$. cordatus and decreased salinity, and Bergin (1981) found that Uca pugilator (Bosc, 1802) releases its larvae at night and during periods of wide tidal amplitudes. Von Hagen (1970) observed that Uca annulipes (Milne-Edwards, 1837) and Uca triangularis (A. Milne Edwards, 1873) copulate during the full and new moon. In $U$. cordatus, the breeding season is marked by a general increase in locomotor activity outside its burrows, together with agonistic behaviors (Góes et al. 2000). However, more detailed assessment of the behaviors associated with the "andada" (walk), also known as the "andança" (gait), "carnaval" (carnival), or "corrida do caranguejo" (crab race) (AlcântaraFilho 1978, Costa 1979, Góes et al. 2000), is desirable.

In the northeast (Diele et al. 2005, Diele and Koch 2010) and southern (Dalabona and Silva 2005) regions of Brazil, the reproduction of the mangrove crab $U$. cordatus is closely associated with the rainy season, similar to that of other semi-terrestrial crabs (Crane 1943, Haley 1972, Henmi 1989, Henmi and Kaneto 1989, Debelius 1999). According to Nascimento (1993), U. cordatus migrates once a year, when the individuals leave their burrows and travel to the sea where they copulate and release their larvae. Fiscarelli and Pinheiro (2002), working at Iguape, São Paulo, reported that $U$. cordatus performs two types of "andada": one for mating and the other for larval release. Diele et al. (2005) and Góes et al. (2000) mentioned that the "andada" of $U$. cordatus occurs on the first days of the full and new moon periods, in synchrony with the wider tidal amplitudes. Further details about the "andada" were recorded by Góes et al. (2000), although they did not quantify this event or evaluate its dynamics or association with environmental factors.

Because of its large size and relative ease of capture, $U$. cordatus has been exploited in many parts of Brazil (Rodrigues et al. 2000, Graser and Diele 2004). Mass mortalities caused by lethargic crab disease (Boeger et al. 2007) supposedly associated with fungus (Pie et al. 2011, Vicente et al. 2012) have decimated entire populations (Monteiro and CoelhoFilho 2004, Vicente et al. 2012). Studies to define the breeding season and the "andada" phenomenon will provide crucial information to assist governmental bodies in reformulating or updating legislation on a protected season for this species. The present study had the objective of determining the mating and breeding seasons, marked by the "andada" phenomenon, assessing its association with environmental factors, and comparing the results with the provisions of the legislation.

\section{MATERIALS AND METHODS}

\section{ENVIRONMENT OF STUDY}

The reproduction of the mangrove crab $U$. cordatus was studied in the Environmental Protection Area of Cananéia, Iguape and Peruíbe (Área de Proteção Ambiental de Cananéia, Iguape e Peruíbe - APA/ 
CIP), located on the southern coast of the state of São Paulo (24 21' 36" S - 46 59' 53" W; $\left.25^{\circ} 18^{\prime} 25^{\prime \prime} \mathrm{S}-48^{\circ} 06^{\prime} 00^{\prime \prime} \mathrm{W}\right)$. The APA/CIP is a lagoon-estuarine complex containing several islands covered by mangrove forests; the complex communicates with the ocean to the north (Barra de Icapara) and the south (Barra de Cananéia), and is bounded by Ilha Comprida, an island $64.6 \mathrm{~km}$ long.

\section{“ANDADA" PHENOMENON}

To analyze the "andada" phenomenon, one mangrove forest was visited daily for six months, from October $1^{\text {st }} 2004$ to March $31^{\text {st }} 2005$, to record the number of crabs moving across the mud surface, and their reproductive behaviors. This observation period was determined following the assessment of the reproductive period described in the literature (Nascimento et al. 1982, Ivo et al. 1999, Góes et al. 2000, Dalabona and Silva 2005). A 10x10 m (100 m²) observation area was marked out, and an observatory was erected in a tree, $3 \mathrm{~m}$ above ground level. The observer, provided with binoculars and a notebook, entered the observatory about 30 minutes prior to the first daily low tide. Remaining silent and motionless for one hour, he recorded the number (in density) of individuals of $U$. cordatus actively moving over the sediment, as well as the following behavioral interactions: 1) confrontation between males (agonistic behaviors), by counting the number of agonistic pairs; 2) release of foam by males, as reported by Góes et al. (2000); and 3) couples in copulation. These behavioral displays were mentioned by Góes et al. (2000) as being associated with the "andada" reproductive behavior. The observations were made between October and March because U. cordatus reproduces in the warmer months of the year (Nascimento et al. 1982, Ivo et al. 1999, Góes et al. 2000, Dalabona and Silva 2005), and the period of low tide was chosen to make the observations because it is not possible to see the crabs when they are submerged.
The date, hour (initial/ final), lunar phase, soil temperature $(10 \mathrm{~cm}$ depth), air temperature $\left(0.1^{\circ} \mathrm{C}\right)$, luminosity (Lux), water salinity $(\%)$, and precipitation $(\mathrm{mm})$ were recorded. Precipitation was recorded daily from a raingauge at the headquarters of the Instituto Brasileiro do Meio Ambiente e dos Recursos Renováveis (IBAMA) situated $1 \mathrm{~km}$ of distance from the observatory, at Iguape, São Paulo. Salnity was measured daily, in water samples collected from three crab burrows.

To estimate when the crabs were active, daytime and nighttime observations were made during the full moon, at the first and second low tides on two consecutive days of the "andada" period in 2005. Two areas of $16 \mathrm{~m}^{2}$ each were defined, and the observer monitored these areas during the day and at night. Nighttime observations were made with the help of a red-light lantern, because crustaceans are less sensitive to this wavelength (Cronin 1986).

“ANDADA" PHENOMENON - STATISTICAL ANALYSES

After test the normality of the data by the Kolmogorov-Smirnov test, the comparisons were made using nonparametric tests. Spearman's correlation was used to assess the association between the environmental (temperature, luminosity, water salinity, precipitation and tide) and behavioral variables (density of active animals and agonistic behaviors). The data for the number of couples in copulation and foaming males were not included in the statistical analyses, because few of these were observed in the marked area during the study. The mean densities of active crabs at spring tide (full and new moon) and neap tide (waxing and waning moon) were compared by Mann-Whitney test. For both tests, the significance level adopted was $P<0.05$ (Zar 1996).

\section{BREEDING SEASON}

For analysis of the $U$. cordatus breeding season, approximately 150 specimens were collected each month for one year (April 2004 through March 2005), 
on a mangrove island near Barra de Icapara at Iguape. Each crab was placed in a separate plastic bag and kept frozen until the analyses. The crabs were thawed at room temperature and washed in running water. Their sex was determined by inspection of the abdominal morphology and number of pleopods (Pinheiro and Fiscarelli 2001), and they were classified into three morphotypes (males, non-ovigerous females, and ovigerous females). The cephalothorax width (SW) was measured with a precision caliper $(0.05 \mathrm{~mm})$.

The animals were dissected to assess the stage of gonadal maturation macroscopically, according to the characteristics given by Pinheiro and Fiscarelli (2001). The breeding season of $U$. cordatus at Iguape was estimated based on the months with the highest percentages of ovigerous females in relation to the monthly total of adult females, compared to the monthly percentage of females with mature gonads in the population, as indicated by Pinheiro and Fransozo (2002). Only adult specimens were used in this analysis (females: LC $>43 \mathrm{~mm}$; males: $\mathrm{LC}>51 \mathrm{~mm}$, according to Pinheiro and Hattori 2006). All procedures were carried out according to the international practices for animal use and care under the control of an internal committee of the Universidade Estadual Paulista, Brazil.

\section{RESULTS}

\section{THE "ANDADA" PHENOMENON}

During the six months of observation, events related to the "andada" (number of active animals and agonistic pairs) of $U$. cordatus were observed from November to February, with typical characteristics in the first two months. During the study, only two couples were recorded in copula, at the end of November and the beginning of December; and a single foaming male was recorded in December (Fig. 1). Figure 1 also shows the range of variation in low

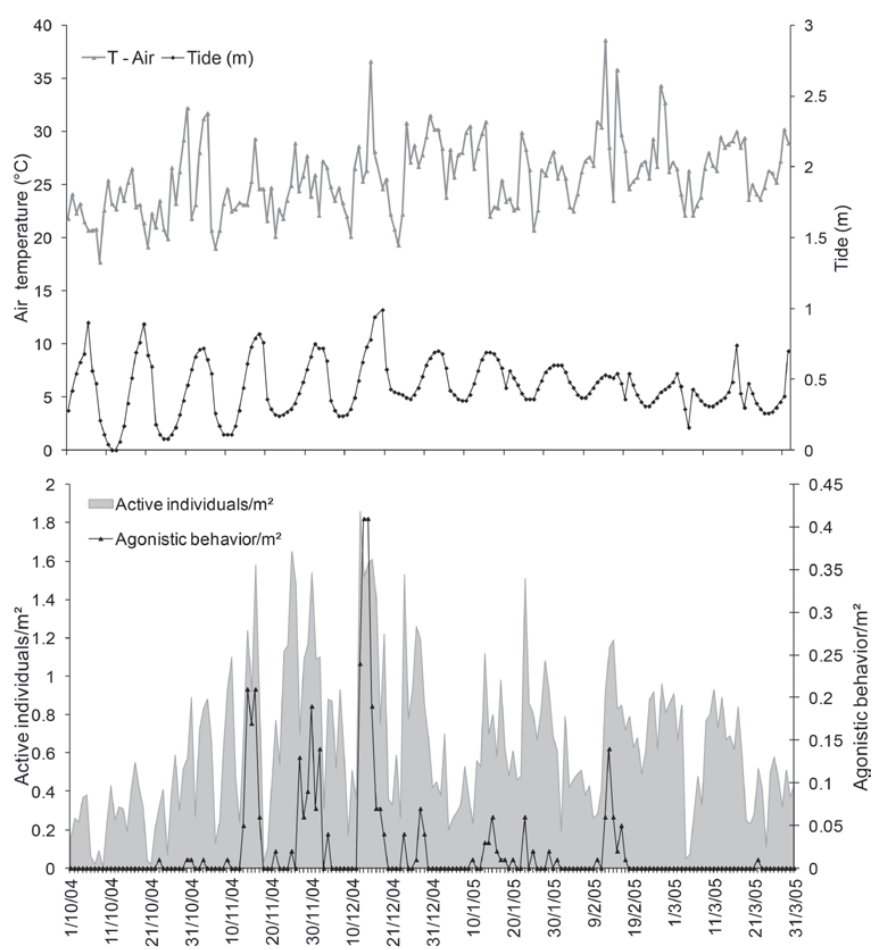

Figure 1 - Ucides cordatus. Daily variation in density (ind. $/ \mathrm{m}^{2}$ ) of active individuals, frequency of agonistic pairs, and air temperature and tidal variation at Iguape, São Paulo. arrow - occurrence of copula; asterisk - occurrence of foaming male. 


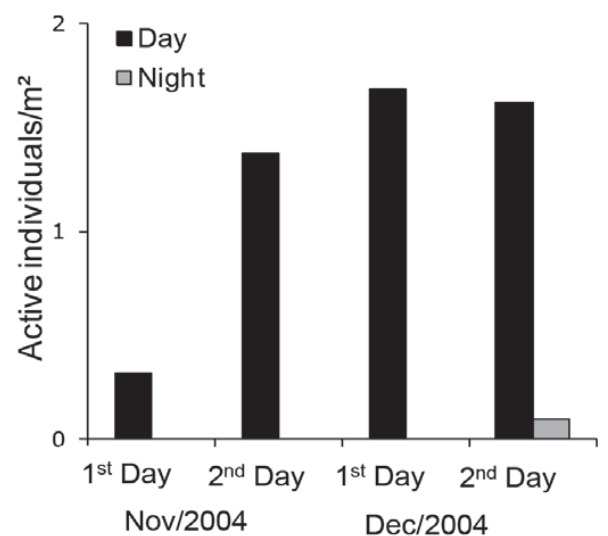

Figure 2 - Ucides cordatus. Density (ind. $/ \mathrm{m}^{2}$ ) of active crabs at low tide during the day and night, in full-moon periods in November and December 2005. tide and air temperature during the study period. The crabs were most active during the day, when all the behavioral events associated with the "andada" were recorded. Few occurrences were seen at night (Fig. 2).

The density of active animals was significant and positively correlated with luminosity and temperature (air and soil), and negatively with salinity $(P<0.05)$ (Table I). The density of agonistic pairs was positively correlated with luminosity, air temperature and tidal amplitude $(P<0.05)$ and negatively with salinity $(P<0.05)$ (Table I).

As described previously, the "andada" occurred in November and December. In this period, the

TABLE I

Correlations of the density of Ucides cordatus, and the density of agonistic pairs, with abiotic factors: luminosity (Lux), soil temperature $\left({ }^{\circ} \mathrm{C}\right)$, air temperature $\left({ }^{\circ} \mathrm{C}\right)$, precipitation $(\mathrm{mm})$, tide $(\mathrm{m})$, and salinity $(\%)$ referring to the six months of observation. $r s=$ Spearman's correlation test value; $* P<0.05$.

\begin{tabular}{cccccc}
\hline Abiotic Factors & $\mathrm{n}$ & $\begin{array}{c}\text { Density of active } \\
\text { animals }(r s)\end{array}$ & $P$ & $\begin{array}{c}\text { Density of animals in } \\
\text { agonistic behavior }(r s)\end{array}$ & $P$ \\
\hline Luminosity & 181 & 0.32 & $<0.0001^{*}$ & 0.31 & $<0.0001^{*}$ \\
Soil temperature & 181 & 0.23 & $0.0015^{*}$ & 0.08 & 0.2838 \\
Air temperature & 181 & 0.38 & $<0.0001^{*}$ & 0.21 & $0.0034^{*}$ \\
Precipitation & 181 & -0.14 & 0.0591 & -0.01 & 0.8089 \\
Tide & 181 & 0.14 & 0.0544 & 0.30 & $<0.0001^{*}$ \\
Salinity & 181 & -0.26 & $0.003^{*}$ & -0.16 & $0.0311^{*}$ \\
\hline
\end{tabular}

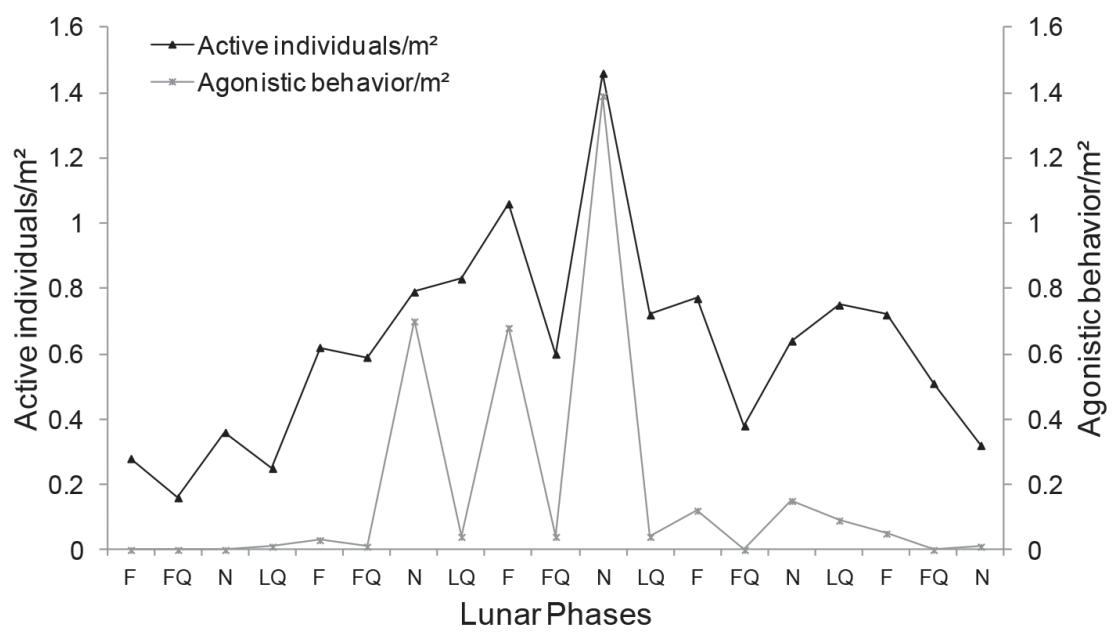

Figure 3 - Ucides cordatus. Mean density $\left(\mathrm{m}^{2}\right)$ of active individuals and agonistic pairs during each lunar phase: full (F), first quarter (FQ), new (N), and last quarter (LQ). 
density of active animals and agonistic behaviors were significantly higher (respectively, $\mathrm{Z}(\mathrm{U})=3.4407$; $P=0.0006$ and $\mathrm{Z}(\mathrm{U})=2.8732 ; P=0.0041$ ) on the days of full and new moon (Fig. 3).

\section{TABLE II}

Ucides cordatus. Numbers of males, females, and ovigerous females collected, and carapace width. Males (M); females (F); ovigerous females (OF); minimum (Min); maximum

(Max); mean (x); and one standard deviation (s).

\begin{tabular}{ccccc}
\hline & & \multicolumn{3}{c}{ Carapace width $(\mathrm{mm})$} \\
\cline { 3 - 5 } Sex & $\mathrm{n}$ & Min & Max & $\mathrm{x} \pm \mathrm{s}$ \\
\hline $\mathrm{M}$ & 1,304 & 51.4 & 85.9 & $66.3 \pm 7.5$ \\
$\mathrm{~F}$ & 429 & 43.2 & 77.0 & $61.6 \pm 8.7$ \\
OF & 68 & 48.8 & 80.0 & $64.0 \pm 7.4$ \\
F+OF & 497 & 43.2 & 80.0 & $61.9 \pm 8.5$ \\
\hline
\end{tabular}

\section{BREEDING SEASON}

A total of 1,801 adult crabs $(1,304$ males, 68 ovigerous females, and 429 non-ovigerous females) were analyzed. Males were the most abundant, and averaged larger than females (Table II).

Adult females with mature gonads were recorded in eight months of the study period (66.7 $\%$, with percentages over $20 \%$ from October through January, and two annual peaks (October and December) (Fig. 4 - A). Adult males with mature gonads were present over most of this period (September through March), although in values lower than $20 \%$; there were three periods of higher incidence (September, November, and February) (Fig. 4 - B). Ovigerous females occurred between December and February, with two peaks (December and February) (Fig. 5), always two months following the peaks of females with mature gonads. Comparison of the monthly percentages of females with mature gonads and ovigerous females indicated that the breeding season of $U$. cordatus in the Iguape region occurred from October through March.

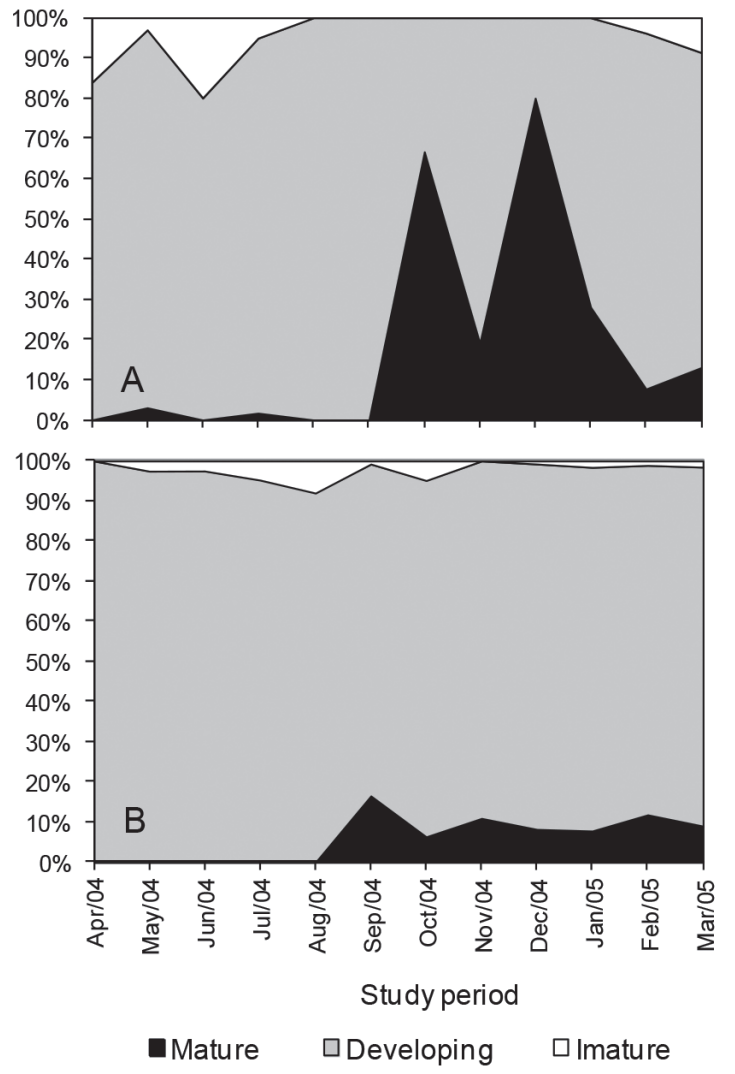

Figure 4 - Ucides cordatus. Percentage of adult females (A) and males (B) with mature gonads, maturing gonads, and immatures caught during the study period, in a mangrove at Iguape, São Paulo.

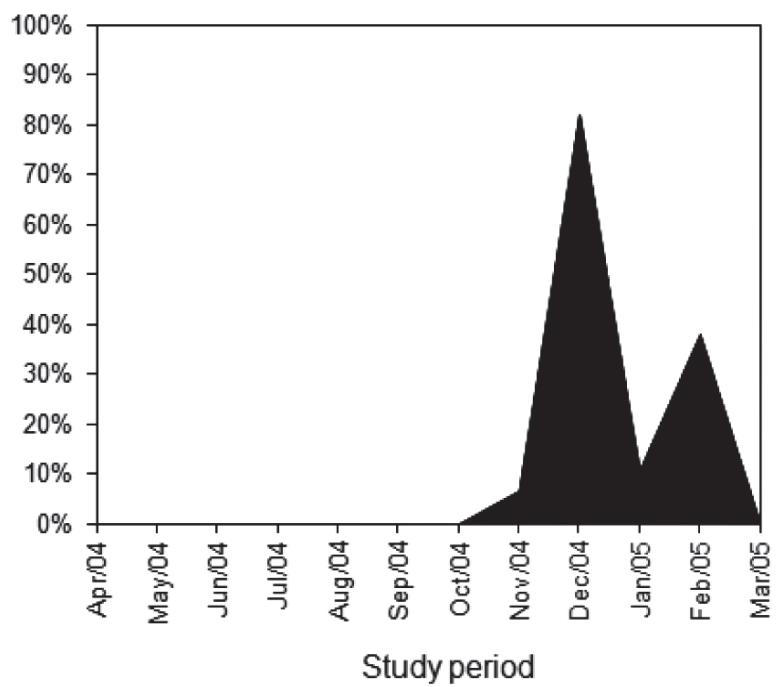

Figure 5 - Ucides cordatus. Percentage of ovigerous females caught during the study period, in a mangrove at Iguape, São Paulo. 
Based on these data, the reproductive cycle of $U$. cordatus at Iguape proceeded as follows: 1) the incidence of females with mature gonads first increased in October; 2) activity of animals and agonistic behaviors ("andada") first increased in November; and 3) the incidence of ovigerous females first increased in December. This cycle was repeated, in the same sequence, from December through February.

\section{DISCUSSION}

Previous studies on breeding season of $U$. cordatus in Brazil showed that it is seasonal, in the warmer months, with a small latitudinal variation (AlcântaraFilho 1978, Nascimento et al. 1972, Ivo et al. 1999, Vasconcelos et al. 1999, Góes et al. 2000, Dalabona and Silva 2005). Diele and Koch (2010), Diele et al. (2005) and Souto (2007) established that there are two annual phases of the life cycle, one related to growth and the other to reproduction, which are antagonistic events in relation to the use of energy in decapod crustaceans (Adiyodi and Adiyodi 1970, Kyomo 1988). The finding of two annual peaks of adult females with mature gonads and ovigerous females at Iguape indicates that $U$. cordatus has split spawning, in contrast to the findings of Dalabona and Silva (2005), who by examining the gonadal histology during the breeding season of $U$. cordatus concluded that this crab spawns only once a year. However, the second peak of the adult females with mature gonads and ovigerous females observed in this study may be related to some females reproducing late.

Although some investigators have analyzed aspects of the reproduction of $U$. cordatus, only Góes et al. (2000) defined its "andada", which occurs from January through April at Vitória in Espírito Santo. In our study, the "andada" occurred over a shorter period, and was most evident in November and December.

Many aquatic organisms show a relationship between reproductive periodicity and the phases of the moon (Korringa 1947, Mileikovsky 1970,
Desjardins 2011, Scharer 2012). In the case of $U$. cordatus in the Iguape mangrove, the "andada"was synchronized with the semi-lunar rhythm, occurring during the full and new moon, in agreement with the results of Diele et al. (2005) and Góes et al. (2000). At Iguape the crabs showed extreme activity during the "andada", even climbing the tree roots in greater densities $\left(1.8 \mathrm{ind} . / \mathrm{m}^{2}\right)$, and with high densities of agonistic pairs of males (more than 0.4 individuals in confrontation $/ \mathrm{m}^{2}$ ). Synchrony of breeding activity with lunar phases is characteristic of the reproduction of semiterrestrial estuarine crabs, as observed by López-Greco and Rodríguez (1999) for the grapsid Chasmagnathus granulata Dana 1851, and for ocypodids of the genus Uca by Von Hangen (1970) and Bergin (1981).

The crab collectors in the Iguape region are aware of the relationship of the "andada" with lunar phases (Fiscarelli and Pinheiro 2002). This crab collector perception agrees with the results of the present study, including the relationship with the lunar phases. We failed to confirm that active animals (according to the crabbers) are more numerous on the days of the full moon than of the new moon, and also the occurrence of two types of "andada", one for mating and another for larval release. Our failure to record these two types of "andada", which were also mentioned by Góes et al. (2000), may be due to the small observation area, although it was necessary to use a small area for greater precision in obtaining density data.

Nordhaus and Wolff (2007) recorded the feeding activity of $U$. cordatus, and observed that the beginning of feeding was correlated with luminosity. A positive correlation of the density of active animals with luminosity and air temperature was registered, as well as a negative correlation with salinity. These results for correlation of salinity appear contradictory. However, in the mangrove observations, on days of heavy rain the crabs were not active, but in the days of decreased rainfall, their activity increased greatly and the rain decreased 
the salinity. The "andada" period, was positively influenced by luminosity and tidal amplitude, and was most intensive in the full and new moon when tidal amplitude is greatest. Although a series of factors may be responsible for initiating the breeding season, temperature is one of the principal factors for marine invertebrates (Geise 1959). Higher temperatures also coincide with greater availability of food for larvae (Zimmerman and Felder 1991). Therefore, it can be expected that the population of $U$. cordatus is subject to a group of environmental parameters that influence mating behaviors.

The records of only two pairs in copula and one foaming male over the entire study period did not prevent us from delimiting the "andada" period, because the other behaviors that we observed (agonistic confrontations between males, and increased density of active crabs) are also closely associated with reproduction (Góes et al. 2000). The possibility that copulations occur more often at night may explain the small number of these records, which were not analyzed in the present study, because the night observations indicate that the "andada" phenomenon occurs during diurnal period. V. Rademaker (unpublished data) also mentioned that individuals of $U$. cordatus mostly remain outside their burrows during the day. Thus, they might copulate during the hours of high tide, although this is contrary to the results of Góes et al. (2000). Because semi-terrestrial crabs copulate during the intermolt and copulation lasts for five hours at most (Hartnoll 1969, Pinheiro 1993), the time of daily observation and the relatively small area observed may have limited the recording of this behavior during the present study.

Mangrove crabs commonly release their larvae at night, as recorded for Cardisoma guanhumi Latreille, 1825 by Gifford (1962); Aratus pisonii (H. Milne Edwards, 1837) by Warner (1967); and Uca pugilator (Bosc, 1802) by Bergin (1981). In the state of Espírito Santo, Góes et al. (2000) observed that females of $U$. cordatus release their larvae in synchrony with the ebb tide, in the early hours of the day. This information corroborates the observation by A.S. Freire (unpublished data) that larval release is associated with the low luminosity at dawn and dusk. Confirming this information, Hattori and Pinheiro (2003), in a laboratory study of the fertility of the mangrove crab, reported that $89.7 \%$ of ovigerous females released their larvae at night. Although $U$. cordatus did not show nocturnal activity during the "andada", probably the ovigerous females left their burrows and made short migrations to the shores of the mangrove at night. It is clear that, knowledge of this species' behavior is still insufficient, and further studies are necessary.

In southern and southeastern Brazil, IBAMA (Portaria \# 52 / 2003) has prohibited the fishing, keeping, and sale of males and females of the mangrove crab in October and November, and of females in December. Because catching ovigerous females is prohibited at any season of the year, and its appears as late as February, the present legislation appears to be adequate although it does not assure that the species is protected during the "andada", which occurs mainly in November and December. In Espírito Santo, the crab fishery has been protected by state legislation during the "andada" period.

The state of Sergipe has also passed legislation that prohibits the catching of this species during the "andada" (Portaria No. 12 of December 2006, IBAMA). In the state of Pará, where the law also prohibits the fishing and sale of the species during the breeding season, including the "andada" period, the crabs are taken continuously disregarding the legislation (Magalhães et al. 2007). The most recent statute is the Normative Instruction No. 1 of 2007 (IBAMA). Among other problems, it is necessary to delimit the "andada" period for each Brazilian region, as well as monitor these occasions.

As previously noted, the results obtained in the present study allowed us to define the "andada"period more reliably for Iguape. The results also suggest that it is best to prohibit the 
catching of both sexes in December and January, or during the days of full and new moon, in these mangrove forests. However, in order to implement these recommendations for species protection, similar studies should be carried out in other Brazilian mangrove areas, to confirm this pattern of the "andada" phenomenon among localities.

\section{CONCLUSIONS}

The "andada" phenomenon occurred from November through February, with typical characteristics in the first two months, when the combined density of active animals and agonistic pairs was the highest, always on the days of the full and new moon. The "andada" was positively influenced by a group of abiotic variables, such as air and soil temperature, luminosity, and tidal amplitude, and negatively influenced by salinity.

The reproductive cycle of $U$. cordatus at Iguape proceeded as follows: 1) the incidence of females with mature gonads first increased in October; 2) activity ("andada") first increased in November; and 3) the incidence of ovigerous females first increased in December. This cycle was repeated, in the same sequence, from December through February.

The results obtained in the present study allowed us to define the "andada" period more reliably. This new information also suggests that it is best to prohibit the fishing of both sexes in December, or during the days of the full and new moon, including January, in the mangrove forests of Iguape, SP, Brazil. Further studies in different areas are necessary to confirm this pattern along the coast of the state of São Paulo and in Brazil, for appropriate implementation of recommendations for the protection of the species.

\section{ACKNOWLEDGMENTS}

We would like to extend our gratitude to the Fundação de Amparo à Pesquisa do Estado de São Paulo (FAPESP, Proc. \# 02/05614-2), for the financial support which made this study possible, as well as to the Instituto Brasileiro do Meio Ambiente (IBAMA) for logistical support and other facilitations. We would also like to thank Dr. Ronaldo A. Christofoletti, and the students of the Research Group in Crustacea Biology (CRUSTA) for their aid in some of the field activities, and Dr. Evandro Severino-Rodrigues and Dr. Acácio Ribeiro Gomes Tomás for their valuable comments. Additional thanks are owed to Dr. Janet W. Reid (JWR Associates) for editing the English text.

\section{RESUMO}

O caranguejo de manguezal Ucides cordatus é um dos crustáceos mais explorados do Brasil. O presente estudo investigou a época reprodutiva desta espécie e o período do fenômeno da "andada", quando os caranguejos estão ativos fora das tocas e ocorrem comportamentos agonísticos. Além disso, estes fatores foram relacionados com fatores ambientais em um manguezal da costa brasileira, com inferência sobre o manejo deste caranguejo. Os caranguejos reproduziram de outubro a fevereiro. A "andada" ocorreu de novembro a fevereiro, com características típicas nos primeiros dois meses, durante os períodos de lua cheia e lua nova, e foi influenciada positivamente pela temperatura do ar e do solo, luminosidade e amplitude de maré e negativamente pela salinidade. Baseado nos resultados do presente estudo, o período quando a "andada"ocorre poderia ser definido em outras partes do Brasil, o que auxiliaria no manejo deste recurso pesqueiro. Para Iguape, Estado de São Paulo, Brasil, sugerimos a proibição da pesca para ambos os sexos durante o mês de dezembro ou durante as luas cheia e nova, incluindo o mês de janeiro.

Palavras-chave: Brachyura, caranguejo, manguezal, manejo, reprodução.

\section{REFERENCES}

ADAMCZEWSKA A AND MORRIS S. 1998. Strategies for migration in the terrestrial Christmas Island red crab Gecarcoidea natalis: intermittent versus continuous locomotion. J Exp Biol 201: 3221-3231.

ADIYODI KG AND ADIYODI RG. 1970. Endocrine control of reproduction in decapod crustaceans. Biol Rev 45: 121-165.

ALCÂNTARA-FILHO P. 1978. Contribuição ao estudo da biologia e ecologia do caranguejo-uçá, Ucides cordatus cordatus (Linnaeus, 1763) (Crustacea, Decapoda, Brachyura) no manguezal do Rio Ceará (Brasil). Arq Ciên Mar 18: 1-41. 
BERGIN ME. 1981. Hatching rhythms in Uca pugilator (Decapoda: Brachyura). Mar Biol 63: 151-158.

Bezerra LEA and Matthews-Cascon H. 2007. Population and reproductive biology of the fiddler crab Uca thayeri Rathbun, 1900 (Crustacea: Ocypodidae) in a tropical mangrove from Northeast Brazil. Acta Oecol 31: 251-258.

Boeger WA, Pie MA, Vicente V, Ostrensky A, Hungria D AND CASTILLO GG. 2007. Histopathology of the mangrove land crab Ucides cordatus (Ocypodidae) affected by lethargic crab disease. Dis Aquat Org 78: 73-81.

BRUSCA RC AND BRUSCA GJ. 20 03. Invertebrates, $2^{\text {nd }}$ ed., Sinauer Associates, Massachusetts, 968 p.

Costa RS. 1979. Bioecologia do Caranguejo-Uçá, Ucides cordatus (Linnaeus, 1763) - Crustacea, Decapoda - no Nordeste Brasileiro. Bol Cea Agr 20: 1-74.

CRANE J. 1943. Display, breeding and relationships of fiddler crabs (Brachyura, Genus Uca) in the northeastern United States. Zoologica 28: 217-223.

CRONIN TW. 1986. Photoreception in marine invertebrates. Am Zool 26: 403-415.

Dalabona G And Silva JL. 2005. Período reprodutivo de Ucides cordatus (Linnaeus) (Brachyura, Ocypodidae) na Baía das Laranjeiras, sul do Brasil. Acta Biol Par 34: 115-126.

DeBelius H. 1999. Crustacea Guide of the World. Atlantic Ocean, Indian Ocean, Pacific Ocean. IKAN Unterwasserarchiv, Frankfurt, $321 \mathrm{p}$.

Desjardins JK, FitzPatrick JL, Stiver KA, VAN Der KRAAK GJ AND BALSHINE S. 2011. Lunar and diurnal cycles in reproductive physiology and behavior in a natural population of cooperatively breeding fish. J Zool 285: 66-73.

DIELE K AND Koch V. 2010. Growth and mortality of the exploited mangrove crab Ucides cordatus (Ucididae) in N-Brazil. J Exp Mar Biol Ecol 395: 171-180.

Diele K, Koch V and Saint-Paul U. 2005. Population structure, catch composition and CPUE of the artisanally harvested mangrove crab Ucides cordatus (Ocypodidae) in the Caeté estuary, North Brazil: indications for overfishing? Aquat Liv Resour 18: 169-178.

Fiscarelli AG AND PINHeIro MAA. 2002. Perfil sócioeconômico e conhecimento etnobiológico dos catadores de Iguape (SP), sobre o caranguejo de mangue Ucides cordatus (Linnaeus, 1763). Actual Biol 24: 129-142.

GEISE AC. 1959. Comparative physiology: annual reproductive cycles of marine invertebrates. Annu Rev Physiol 21: 547-576.

GIFFORD CA. 1962. Some observations on the general biology of a land crab, Cardiosoma guanhumi (Latreille), in South Florida. Biol Bull 123: 207-223.

GóEs P, SAMPAIO FDF, CARMO TMS, TÔSO GC AND LEAL MS. 2000. Comportamento e períodos reprodutivos do caranguejo do mangue Ucides cordatus. Anais do V Simpósio de Ecossistemas Brasileiros: Conservação. Vitória, Espírito Santo 2: 335-348.
GRASER M AND DIELE K. 2004 Asymmetric outcomes: Assessing central aspect of biological, economical and social sustainability of a mangrove crab fishery, Ucides cordatus (Ocypodidae), in North Brazil. Ecol Econ 49: 361-373.

HALEY SR. 1972. Reproductive cycling in the ghost crab, Ocypode quadrata (Fabr.) (Brachyura, Ocypodidae). Crustaceana 23: 1-11.

HARTNOLL RG. 1969. Mating in the Brachyura. Crustaceana 16: 161-181.

HATTORI GY AND PINHEIRO MAA. 2003. Fertilidade do caranguejo de mangue Ucides cordatus (Linnaeus) (Crustacea, Brachyura, Ocypodidae), em Iguape (São Paulo, Brasil). Rev Bras Zool 20: 309-313.

HENMI Y. 1989. Life-history patterns in two forms of Macrophthalmus japonicus (Crustacea, Brachyura). Mar Biol 101: 53-60.

HENMI Y AND KANETO M. 1989. Reproductive ecology of three ocypodid crabs I. The influence of activity differences on reproductive traits. Ecol Res 4: 17-29.

IBAMA. 1994. Lagosta, Caranguejo-Uçá e Camarão-doNordeste. Coleção Meio Ambiente. Série Estudos-Pesca, v.10, Brasília.

IBAMA. 2003. Portaria No. 52, 30 September.

IBAMA. 2006. Portaria No. 12, December.

IBAMA. 2007. Instrução normativa No. 1, 2 January.

Ivo CTC, DiAs AF AND MotA RI. 1999. Estudo sobre a Biologia do caranguejo uçá, Ucides cordatus cordatus (Linnaeus, 1763), capturado no Delta do Rio Parnaíba, Estado do Piauí. Bol Téc Cien 7: 53-84.

KORRINGA P. 1947. Relations between the moon and periodicity in the breeding of marine animals. Ecol Monogr 17: 347-381.

KYOMO J. 1988. Analysis of the relationship between gonads and hepatopancreas in males and females of the crab Sesarma intermedia, with reference to resource use and reproduction. Mar Biol 97: 87-93.

LiTULO C. 2006. Population and reproductive biology of the fiddler crab Uca chlorophthalmus (Brachyura: Ocypodidae) from Inhaca Island, southern Mozambique. J Mar Biol Assoc UK 86: 737-742.

LÓPEZ-GRECO LS AND RoDRÍGUEZ EM. 1999. Annual reproduction and growth of adult crabs Chasmagnathus granulata (Brachyura, Grapsidae). Cah Biol Mar 40: 155-164.

Magalhães A, Costa RM, Silva M ANd Pereira LCC. 2007. The role of women in the mangrove crab (Ucides cordatus, Ocypodidae) production process in North Brazil (Amazon region, Para). Ecol Econ 61: 559-565.

MileIKovsKy SA. 1970. Seasonal and daily dynamics in pelagic larvae of marine shelf bottom invertebrates in nearshore waters of Kandalaksha Bay (White Sea). Mar Biol 5(3): 180-194.

MONTEIRO BR AND COELHO-FILHO PA. 2004. Estrutura populacional do caranguejo-uçá, Ucides cordatus (Linnaeus, 1763) (Crustacea, Decapoda, Ocypodidae), no estuário do Rio Paripe, Itamaracá - Pernambuco. Bol Téc Cien 12: 99-111. 
NASCIMENTO SA. 1993. Biologia do Caranguejo-Uçá (Ucides cordatus). Sergipe Administração Estadual do Meio Ambiente (ADEMA), 45 p.

NAscimento SA, SAntos ER, Bonfim L And Costa RS. 1982. Estudo Bio-Ecológico do Caranguejo Uçá Ucides cordatus. Sergipe: Administração Estadual do Meio Ambiente (ADEMA), 12 p.

NoRDHAUS I AND WOLFF M. 2007. Feeding ecology of the mangrove crab Ucides cordatus (Ocypodidae): food choice, food quality and assimilation efficiency. Mar Biol 151: 1665-1681.

OLIVEIRA LPH. 1946. Estudos ecológicos dos crustáceos comestíveis Uçá e Guaiamu, Cardisoma guanhumi Latreille e Ucides cordatus (L.) Gecarcinidae, Brachyura. Mem Inst Osw Cruz 44: 295-322.

Pie Mr, Boeger WA, Patella L, Vicente VA, Ribeiro RO AND OSTRENSKY A. 2011. Specific primers for the detection of the black-yeast fungus associated with lethargic crab disease (LCD). Dis Aquat Org 94: 73-75.

PINHEIRO MAA. 1993. Comportamento copulatório de Panopeus rugosus A. M. Edwards, 1880 (Crustacea, Brachyura, Xanthidae) em cativeiro. Biotemas 6:115-120.

PINHEIRo MAA, BAVELONI MD AND TERCEIRO OSL. 2003. Fecundity of the mangrove crab Ucides cordatus (Linnaeus, 1763) (Crustacea, Brachyura, Ocypodidae) at Iguape, SP, Brazil. Int J Invert Repr Dev 43: 19-26.

PinheIro MAA AND FisCARELli AG. 2001. Manual de Apoio à Fiscalização do Caranguejo-Uçá (Ucides cordatus). $1^{a}$ Edição, Cepsul/Ibama, Itajaí, 43 p.

PINHEIRO MAA AND FRANSOZO A. 2002. Reproduction of the speckled swimming crab Arenaeus cribrarius (Brachyura: Portunidae) on the Brazilian coast near $23^{\circ} 30^{\prime} \mathrm{S}$. J Crust Biol 22: 416-428.

PINHEIRO MAA AND HATTORI GY. 2003. Embryology of the mangrove crab Ucides cordatus (Linnaeus, 1763) (Brachyura, Ocypodidae). J Crust Biol 23: 729-737.

PINHEIRO MAA AND HATTORI GY. 2006. Relative growth of the mangrove crab Ucides cordatus (Linnaeus, 1763) (Crustacea, Brachyura, Ocypodidae) at Iguape, São Paulo, Brazil. Brazilian Arch Biol Technol 49: 813-823.
Rodrigues AMT, BRANCO EJ, SACCARDO AS AND BlANKENSTEYN A. 2000. A exploração do caranguejo Ucides cordatus (Decapoda: Ocypodidae) e o processo de gestão participativa para normatização da atividade na Região Sudeste-Sul do Brasil. Bol Inst Pesca 26: 63-78.

SANT'ANNA BS, PINHEIRO MAA, MATAQUEIRO M AND ZARA FJ. 2007. Spermathecae of the mangrove crab Ucides cordatus: a histological and histochemical view. J Mar Biol Assoc UK 87: 903-911.

SCHARER MT, NEMETH MI, MANND, LOCASCIOJ, APPELDOORN RS AND ROWELL TJ. 2012. Sound production and reproductive behavior of yellowfin grouper, Mycteroperca venenosa (Serranidae) at a spawning aggregation. Copeia 1: 134-144.

SoUTO FJB. 2007. Uma abordagem etnoecológica da pesca do caranguejo, Ucides cordatus, Linnaeus, 1763 (Decapoda: Brachyura), no manguezal do Distrito de Acupe (Santo Amaro-BA). Biotemas 20(1): 69-80.

VASCONCELOS SEM, VASCONCELOS JA AND IVO CTC. 1999. Estudo sobre a biologia do caranguejo Uçá, Ucides cordatus cordatus (Linnaeus, 1763), capturado no Estuário do Rio Curimatau (Canguaretama) no estado do Rio Grande do Norte. Bol Téc Cient (Cepene) 7: 75-116.

VICENTE AV ET AL. 2012. Black yeast-like fungi associated with lethargic Crab Disease (LCD) in the mangrove-land crab, Ucides cordatus (Ocypodidae). Vet Microbiol 158: 109-122.

Von HANGeN OH. 1970. Anpassugen an das spezielle Gezeitenzonenniveau bei Oxypodiden (Brachyura, Ocypodidae). Form Fun 2: 361-413.

WARNER GF. 1967. Life history of the mangrove tree crab, Aratus pisoni. J Zool 153: 321-335.

ZAR JH. 1996. Biostatistical Analysis. $3^{\text {rd }}$ ed., New Jersey: Prentice-Hall Inc.

ZIMMERMAN TL AND FELDER DL. 1991. Reproductive ecology of an intertidal Brachyuran crab, Sesarma sp (nr reticulatum), from the Gulf-of-Mexico. Biol Bull 181: 387-401. 